Z. Klin. Chem. Klin. Biochem.

13. Jg. 1975 , S. $319-323$

\title{
The Effect of Fluorocarbon FC 43 on the Metabolism of Steroids during Perfusion of the Isolated Rat Liver
}

\author{
By $M$. Höller and H. Breuer \\ Institut für Klinische Biochemie der Universität Bonn, F. R. Germany
}

(Eingegangen 21. März/23. Mai 1975)

Summary: The influence of fluorocarbon FC 43 on the metabolism of oestrogens in the isolated perfused rat liver was investigated. In comparative once-through perfusions with FC 43 emulsion or albumin solution as perfusion medium, the clearance rates of oestrone and its metabolites were determined. In perfusions with FC 43 , the clearance of oestrone was lower, and the metabolites formed in the liver were more concentrated in the outflowing medium than in perfusions without fluorocarbon. This can be explained by the high affinity, even of conjugated oestrogens, to FC. 43 , which is established by equilibrium dialysis and partition coefficient. The results presented here show that the fluorocarbon has a strong influence of its own on the metaholism of steroids in the isolated perfused liver. Therefore, this solvent should be avoided as medium when the metabolism of steroids is studied in perfusion experiments.

\section{Einfluß von Fluorcarbon FC 43, auf den Stoffwechsel von Steroiden während Perfusion der isolierten Rattenleber}

Zusammenfassung: Der Einfluß von Fluorcarbon FC 43 auf den Stoffwechsel von Steroiden in der isoliert perfundierten Rattenleber wurde untersucht. Zu diesem Zweck wurde eine Emulsion mit $150 \mathrm{ml} / \mathrm{l}$ FC 43 oder eine Pufferlösung mit $30 \mathrm{~g} / 1$ Albumin nicht-zyklisch durch Rattenlebern perfundiert. Beide Medien enthielten gleiche Konzentrationen von $\left[4{ }^{14} \mathrm{C}\right]$ Östron. Das ausfließende Medium wurde fraktioniert aufgefangen und analysiert. Es zeigte sich, daßs die Clearance von Östron bei Perfusionen mit FC 43-haltigem Medium deutlich niedriger ist als in Versuchen mit fluorcarbonfreiem Medium; gleichzeitig werden die in der Leber entstehenden Metaboliten auf Grund ihrer Affinität zu FC 43 schneller an das Medium abgegeben. Die relativ große Affinität wurde durch Gleichgewichtsdialyse und Untersuchungen ïber den Verteilungskoeffizienten nachgewiesen. Die hier vorgelegten Ergebnisse führen zu dem Schluß, daßs ein Medium, welches Fluorcarbon FC 43 enthält, zum Studium des Stoffwechsels von Steroiden in der isoliert perfundierten Rattenleber nicht geeignet ist.

\section{Introduction}

During the last years, there has been an increasing use of fluorocarbons in bioscience $(1-4)$. Because of the high solubility of oxygen in these inert, organic liquids, they can be used as substitutes for hemoglobin, which is the physiological oxygen carrier. Organ perfusions with fluorocarbon may be performed with fluorocarbon liquid alone, or with fluorocarbon emulsified in a physiological salt medium. Fluorocarbon emulsions have been used as blood substitutes in perfused liver $(3,4)$, brain $(5,6)$ and kidney (2). Recently, a successful long-term perfusion of the isolated rat liver has been described, during which the induction of enzymes was demonstrated (7). In spite of many investigations, the properties of fluorocarbons and their influence on tissues and cells are not fully understood. Interesting observations on the oxygen absorption coefficient (8) and the influence of fluorocarbon on NADH oxidation $(9,10)$ have been published.

An optimal perfusion medium has to meet the following requirements:

(1) adequate oxygen capacity,

(2) no physical or biochemical side effects on the perfused organ,

(3) stability of the medium during perfusion and

(4) no effects on the metabulism which is to be investigated by the perfusion.

The oxygen capacity of a $150 \mathrm{ml} / \mathrm{l}$ fluorocarbon emulsion is about three times as high as the capacity of a hemoglobin-frec buffer solution. With a flow rate of about $1.2 \mathrm{ml} / \mathrm{g}$ wet weight/min, oxygen supply should be guaranteed at $37^{\circ} \mathrm{C}$ in the isolated rat liver. Several 
other aspects must also be considered, including the stability of the emulsion during the time of perfusion, the possibility of segregation of fluorocarbon particles and buffer from each other, and finally, the high viscosity of the emulsion; some of these difficulties have recently been overcome (7). A further point needs to be considered. If the metabolism of a lipophilic substance or the metabolism of a substance which may be regulated by a liphophilic substance is investigated by perfusion experiments, the question arises whether the lipophilic fluorocarbon has an effect of its own on the processes to be studied.

The present investigation was undertaken to see if the metabolism of oestrone is influenced by fluorocarbons. Comparative perfusions were carried out with

(a) buffer solutions,

(b) buffer solutions containing $30 \mathrm{~g} / \mathrm{l}$ albumin and

(c) fluorocarbon buffer emulsions (fluorocarbon $150 \mathrm{ml} / \mathrm{l}$ ).

In additional in vitro studies, the partition coefficients of various oestrogens between fluorocarbon particles and the aqueous phase in a fluorocarbon emulsion was investigated. Moreover, the concentration of the free, unbound oestrone was determined by equilibrium dialysis of the different perfusion media against buffer solution.

\section{Experimental}

\section{Material}

$\left[4-{ }^{14} \mathrm{C}\right]$ Oestrone (specific activity $58 \mathrm{Ci} / \mathrm{mol}$ ), $\left[6,7-{ }^{3} \mathrm{H}_{2}\right]$ oestriol (specific activity, $50 \mathrm{Ci} / \mathrm{mmol}$ ), $\left[6,7-{ }^{3} \mathrm{H}_{2}\right]$ oestradiol-17 $\beta$ : $17 \beta$-glucuronide (specific activity $29.5 \mathrm{Ci} / \mathrm{mmol}$ ) and $\left[6,7-{ }^{3} \mathrm{H}_{2}\right]$ oestrone sulphate (specific activity $54 \mathrm{Ci} / \mathrm{mmol}$ ) were purchased from the Radiochemical Centre, Amersham, England, and New England Nuclear Corporation, Waltham, Mass., U.S.A. The non-radioactive steroids were purchased from Ikapharm, Ramat-Gan, Israel, and Schering, Berlin, or were placed at our disposal by Dr. G. Röhle, Institut für Klinische Biochemie der Universität Bonn. All steroids were tested for purity by thin-layer chromatography.

Fluorocarbon FC 43 perfluorotributyl amine was purchased from the $3 \mathrm{M}$ Company, Düsseldorf, and the polyol Pluronic F-68 from Erbsloeh, Düsseldorf (Wyandotte Chemical Corp., Wyandotte, Mich., U.S.A.). The chemical nature of FC 43 and Pluronic F-68 have been previously reported $(11,12)$.

\section{Preparation of perfusion media}

Three different perfusion media were used. The first consisted of Krebs hydrogen carbonate buffer, the second of Krebs hydrogen carbonate buffer, containing $30 \mathrm{~g} / 1$ bovine serum albumin (Behring, Marburg); the third was an emulsion of fluorocarbon FC 43 in Krebs hydrogen carbonate buffer, containing $50 \mathrm{~g} / 1$ Pluronic (F-68) polyol as emulsifying agent. The emulsion was prepared as described by Krone et al. (7) except that before insonation, the mixture was homogenised in an Ultra-Turrax (Janke \& Kunkel, Staufen i. Breisgau). This dispersion was insonated with a Braun Sonic $300 \mathrm{~S}$ (Braun, Melsungen) for $2 \mathrm{~h}$ in a $250 \mathrm{ml}$ vessel, which allows repeated insonation by constant circulation of the medium; the sonifier yielded an energy of - bout $280 \mathrm{~W}$. The emulsion thus obtained was filtered through Whatman no. 1 and Whatman no. 3 filter papers and found to be stable; it was frozen and stored at $-20^{\circ} \mathrm{C}$ as described elsewhere (7). The oxygen absorption coefficient of a $150 \mathrm{ml} / 1$ fluorocarbon emulsion at $37^{\circ} \mathrm{C}$ was determined and calculated to be $\alpha=0.07517 \pm 0.00252$. The coefficient was constant between
120 and $650 \mathrm{~mm} \mathrm{Hg}$ oxygen pressure. The oxygen absorption coefficient for the fluorocarbon-free perfusion media was taken as $\alpha=0.02273$ (14). Both media were dialysed against buffer solution before use.

\section{Animals and perfusion technique}

Male Wistar rats $(300-320 \mathrm{~g})$ were used in all experiments (Institut für Versuchstierzucht, Hannover). Following anesthesia with intraperitoneal sodium pentobarbital $(50 \mathrm{mg} / \mathrm{kg}$ body weight), the abdomen was opened, the portal vein cannulated and the liver flushed with oxygenated Krebs hydrogen carbonate buffer (13). The liver was then transferred to the perfusion apparatus and non-cyclically perfused at $37^{\circ} \mathrm{C}$ with perfusion medium which was equilibrated in a disc oxygenator with a humidified $\mathrm{O}_{2} / \mathrm{CO}_{2}$ mixture (volumes, $950 \mathrm{ml}+50 \mathrm{ml}$ ). The perfusion apparatus and glassware were similar to that described previously (13). Each perfusion medium contained $1 \mathrm{mg} / \mathrm{l}$ $\left[4^{-14} \mathrm{C}\right.$ ]oestrone (specific radioactivity $18 \mathrm{Ci} / \mathrm{mol}$ ). The oxygenated medium was transported to the organ by a roller pump (Varioperpex, LKB, München). The flow rate was adjusted to $1 \mathrm{ml} / \mathrm{g}$ organ wet weight/min and was continuously monitored by an electromagnetic flowmeter (model SP 2202, Statham Instruments, c/o Schubarth, Wiesbaden). The perfusion pressure before the entry of the canula into the vena portae was continuously determined (blood pressure monitor, model SP 1400, with transducer P $23 \mathrm{Db}$, Statham Instruments, c/o Schubarth, Wiesbaden). Oxygen tension in artcrial and venous media were measured as described previously (13). The oxygen consumption of the liver was calculated from the flow rate and the arterialvenous difference in oxygen tension. The liver weight was determined before and after pcrfusion. The venous medium was collected in $10 \mathrm{ml}$ fractions. To prevent oxidative decomposition of labile metabolites of oestrone, approximately $100 \mathrm{mg}$ ascorbic acid was added to each $10 \mathrm{ml}$-fraction.

\section{Determination of oestrone and its metabolites}

After measurement of the radioactivity, each fraction was applied to an Amberlite XAD-2 column $(25 \times 1 \mathrm{~cm})(15)$. Each column was rinsed with $100 \mathrm{ml}$ of destilled water and $30 \mathrm{ml}$ water/methanol (volumes, $30 \mathrm{ml}+10 \mathrm{ml}$ ). The wash phases which contained less than $5 \%$ of the radioactivity of the fraction were discarded. After clution of the resin with methanol and acetone, the eluates were evaporated to dryness and the residues dissolved in a small volume of methanol; chromatography was carried out on thin-layer platcs (silica gel $F_{254}$, Merck, Darmstadt) in cyclohexane/chloroform/acetic acid (volumes $100 \mathrm{ml}+$ $100 \mathrm{ml}+100 \mathrm{ml}$ ) and benzene/ethanol (volumes, $85 \mathrm{ml}+15 \mathrm{ml}$ ). Authentic steroids were used as parallel standards. The standards were visualized by spraying the plates with $50 \mathrm{~g} / \mathrm{l}$ sulphuric acid in methanol. Areas of radioactivity were located by using a radiochromatogramm scanner (Berthold, Modell II, Karlsruhe). Single, distinct peaks of radioactivity were obtained. The peaks were eluted from the thin-layer plates with a mixture of methanol/ acetone (volumes, $30 \mathrm{ml}+10 \mathrm{ml}$ ). Radioactivity was measured in a Nuclcar Chicago liquid scintillation counter (model Mark II). Samples were counted in $10 \mathrm{ml}$ dioxane, containing $7 \mathrm{~g} \mathrm{PPO}$, $0.3 \mathrm{~g}$ dimethyl-POPOP and $100 \mathrm{~g}$ naphthalene in 11 dioxane. All results were corrected for losses occurring during elution and chromatography.

\section{Partition of oestrogens in a FC 43 emulsion between lipophilic and water phase}

Various amounts of methanolic solutions of radioactiv labelled oestrone, oestriol, oestradiol-17 $\beta 17 \beta$-glucuronide and oestrone sulphate were pipetted into different tubes; the solvent was evaporated under vacuum. The steroids were resolved in $10 \mathrm{ml}$ of a $300 \mathrm{ml} / \mathrm{l} \mathrm{FC} 43$ emulsion. After slight shaking for $30 \mathrm{~min}$, the emulsions were centrifuged in a Christ Zeta 20 centrifuge at $25^{\circ} \mathrm{C}$ for $20 \mathrm{~min}$ at $20000 \mathrm{gav}_{\mathrm{av}}$. The radioactivity in the lipophilic pellet was determined.

\section{Determination of unbound oestrone in albumin solution and FC 43 emulsion}

The dialysis equilibrium of oestrone between FC 43 emulsion or albumin solution on the one hand and buffer solution on the 
other hand or between FC 43 emulsion and albumin solution was determined in a Dianorm BFD (batch flow dialy sis) system (Diachema, Zürich) with a Visking cellulose membrane (Union Carbide). The equilibrium was determined after $8 \mathrm{~h}$ dialysis at $37^{\circ} \mathrm{C}$.

\section{Results}

\section{Functioning states of the liver}

After perfusion of rat liver under the conditions described, no increase of organ weight was observed. From this it may be concluded that there was no oedema. Because of the high viscosity of the FC 43 emulsion, perfusion pressure was between 32 and $38 \mathrm{~mm} \mathrm{Hg}$ instead of 14 tc $18 \mathrm{~mm} \mathrm{Hg}$ in perfusions with solutions containing albumin. The oxygen consumption of the liver was between 1.86 and $1.91 \mu \mathrm{mol} / \mathrm{min} / \mathrm{g}$ wet weight in perfusions with FC 43 emulsion. This oxygen consumption is approximately adequate at a temperature of $37^{\circ} \mathrm{C}$ (16). When an albumin-containing solution was used as perfusion medium, oxygen supply was inadequate at a perfusion rate of $1 \mathrm{ml} / \mathrm{min} / \mathrm{g}$ wet weight; oxygen consumption was found to be $0.63 \mu \mathrm{mol} / \mathrm{min} / \mathrm{g}$ wet weight.

\section{Clearance of total steroids and clearance of oestrone in a once-through perfusion}

Calculations of clearance were made according to the following formula:

$$
\frac{\frac{\text { amount }_{\text {in }}-\text { amount }_{\text {out }}(\mathrm{g})}{\mathrm{t}(\mathrm{s})}}{\text { concentration in perfusion medium }(\mathrm{g} / \mathrm{ml})}=\underset{(\mathrm{ml} / \mathrm{s}) .}{ }
$$

The clearance rates of oestrone and of total steroids in perfusion experiments with albumin solution and with FC 43 emulsion are shown in the figure. Only small differences were observed in the first fractions; however, they increased in the later fractions. The clearance rates of total steroids decreased during perfusion and became linear in the last fractions of both perfusion media. The decreasing slope in the clearance rates of oestrone is the result of the fact that, at the beginning of the perfusion, no oestrone is present inside the liver. From the fourth fraction on, the clearance of oestrone parallels the $\mathrm{x}$-axis for both perfusion media. The clearance rate of oestrone and of total steroids are higher in perfusions with albumin than in those with FC 43 emulsions.

\section{Partition of various oestrogens between lipophilic and water phase in a FC 43 emulsion}

The partition coefficients of various oestrogens between buffer and FC 43 fluorocarbon are summarised in table 1 . The data prove that, in a FC 43 emulsion, steroids are enriched in the lipophilic fluorocarbon particles. The concentration depends.on the polarity of the steroid; the more lipophilic a steroid is, the more it is concentrated in the FC 43-particles.
Tab. 1. Partition coefficients of various oestrogens between buffer solution and FC 43 fluorocarbon. Concentrations of stcroids were measured in the aqueous phase and in the fluorocarbon solution.

\begin{tabular}{ll}
\hline Steroid & Partition coefficient \\
\hline Oestrone & 0.095 \\
Oestriol & 0.20 \\
Oestradiol-17 $\beta$ & 0.24 \\
$\quad$ 17 $\beta$-glucuronide & 0.18 \\
Oestronc sulphate & \\
\hline
\end{tabular}

\section{Dialysis equilibrium of oestrone between buffer and FC 43 emulsion and between buffer and albumin solution}

The results of the dialysis equilibrium are presented in table 2 . The steroid is not bound by the membrane; this is shown by equilibrium dialysis between the same media. Binding of oestrone to albumin and fluorocarbon is calculated from the results of equilibrium dialysis. In a buffer solution with $30 \mathrm{~g} / \mathrm{l}$ albumin, $25.5 \%$ of the oestrone is unbound, whereas in a FC 43 emulsion, only $12.4 \%$ is not bound.

Tab. 2. Equilibrium dialysis of oestrone between various media. Duration of dialysis: $8 \mathrm{~h}$. Temperature: $37^{\circ} \mathrm{C}(\mathrm{n}=4)$.

\begin{tabular}{lll}
\hline $\begin{array}{l}\text { Medium containing } \\
1 \mathrm{mg} / \mathrm{l} \text { oestrone }\end{array}$ & $\begin{array}{l}\text { Dialysed against } \\
\text { oestrone-free } \\
\text { medium }\end{array}$ & $\begin{array}{l}\text { \% of radioactivity } \\
\text { rumaining in the } \\
\text { initial medium ( } \pm \text { SD) }\end{array}$ \\
\hline FC 43 emulsion & FC 43 emulsion & $53.3 \pm 1.2 \%$ \\
FC 43 emulsion & albumin solution & $58.4 \pm 2.9 \%$ \\
FC 43 emulsion & buffer solution & $89.1 \pm 4.3 \%$ \\
albumin solution & albumin solution & $54.1 \pm 2.0 \%$ \\
albumin solution & buffer solution & $82.7 \pm 1.3 \%$ \\
buffer solution & buffer solution & $51.3 \pm 0.9 \%$ \\
\hline
\end{tabular}

\section{Discussion}

In perfusion experiments, three different types of perfusion media may be employed:

(1) media containing erythrocytes,

(2) hemoglobin-free solutions containing albumin and

(3) emulsions containing fluorocarbon in buffer.

In the present study, only the latter two media have been used; since in spite of the oxygen-binding capacity of hemoglobin, perfusions carried out with media containing red blood cells suffer from many disadvantages. These include clumping and disruptions of the erythrocytes, leading to reduced microcirculation and embolism, and also active participation in the metabolism of the substances under investigation. Special conditions had to be chosen for the once-through perfusions, in order to compare clearance rates of oestrone in the different media. This implies, as previously mentioned, that the oxygen supply was not adequate in those perfusion experiments in which albumin-containing media were used. 


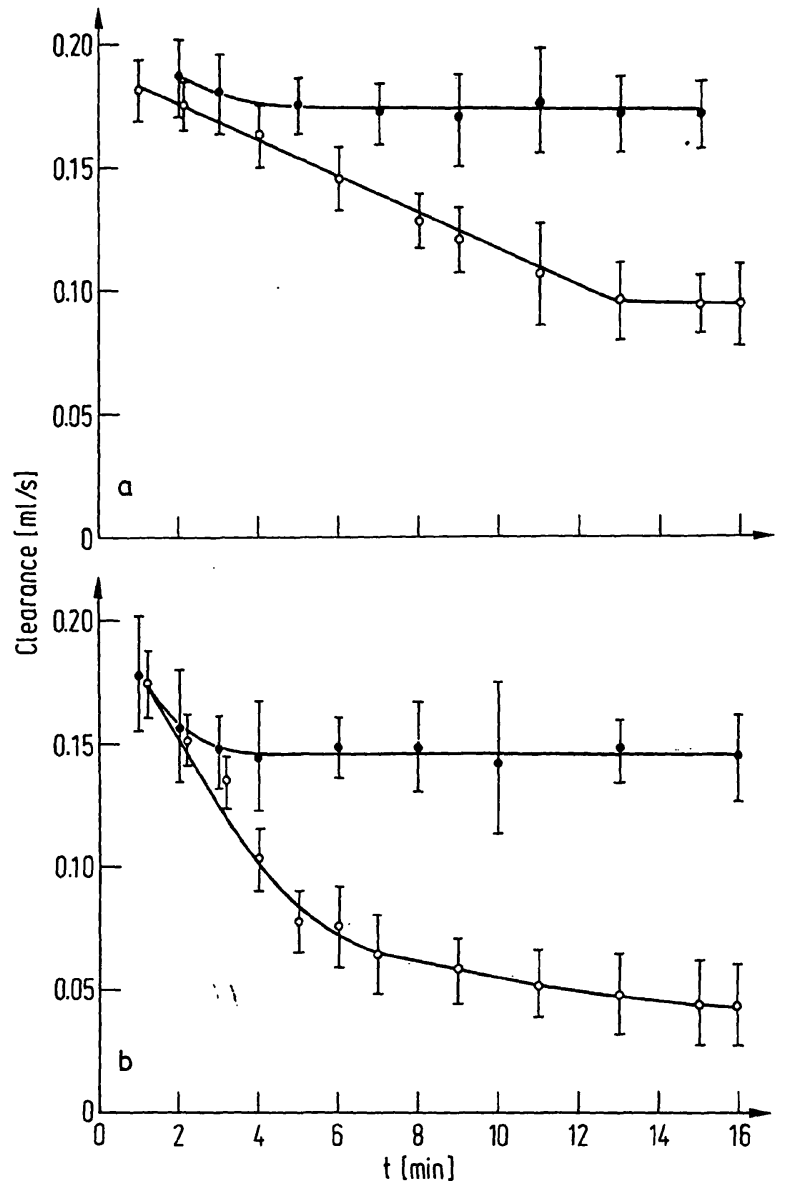

Fig. 1. Comparison of the clearance rates of oestrone and total steroids in once-through perfusions of the isolated rat liver with different perfusion media.

a) perfusion with buffer-albumin medium;

b) perfusion with FC 43 emulsion. The clearance rates were calculated from the different fractions of the venous outflow.

\begin{tabular}{ll}
$\longrightarrow$ Total steroids & $\bar{x} \pm s ; n=4$ \\
\hline Oestrone & $\bar{x} \pm s ; n=4$
\end{tabular}

In the present investigation, it has been shown that fluorocarbon $\mathrm{FC} 43$, which is frequently used as an oxygen carrier in perfusion studies, influences the metabolism of steroids in isolated, perfused rat liver. Lipophilic substances are concentrated in the lipophilic fluorocarbon phase of a fluorocarbon/water emulsion. The binding of oestrone by FC 43 is well established by the results of equilibrium dialysis and by the partition coefficient for various oestrogens between buffer and FC 43 . The coricentration of free oestrone in albumin solution is twice as high as in FC 43 emulsion. The hepatic extraction by the isolated perfused rat liver is reduced in perfusions carried out with a fluorocarbon emulsion, as compared with perfusions with an albumin solution. In the first instance, the extraction is about $77 \%$, whereas in the second case it is about $95 \%$. The clearance rate of oestrone, a substance rapidly metabolised, may depend on the supply of the liver with free oestrone $(17,18)$; this supply is reduced in perfusions with FC 43.

In experiments using a medium containing only pluronic F-68 $(50 \mathrm{~g} / \mathrm{l}$ in buffer $)$, the clearance rates of oestrone were identical with those observed in perfusions with albumin containing media. This was to be expected, since the extraction of oestrone from albumin-containing solutions is almost quantitative.

The difference between the clearance rates of oestrone and the clearance rates of total steroids is higher in perfusions with FC 43 emulsions than in perfusions with albumin-containing media. The partition coefficient of metabolites of oestrone shows a strong binding to fluorocarbon; this is even true for the conjugates. It may be assumed that, because of the high affinity of FC 43 to the metabolites which are formed in the liver, they may be 'extracted' into the perfusion medium, depending on their partition coefficients. The sum of both effects leads to a reduction of the clearance rates of total steroids in perfusions with FC 43 to about $51 \%$ of the clearance rate observed in perfusions with albumin solution. In conclusion, the results presented in this paper leave no doubt that fluorocarbon FC 43 should not be used in perfusion experiments in which the metabolism of steroids is to be studied.

\section{Acknowledgements}

This investigation was supported by the Deutsche Forschungsgemeinschaft. The authors wish to thank Dr. Rosemarie Baumann, Physiologisches Institut, Medizinische Hochschule Hannover, for the measurement of the $\mathrm{O}_{2}$-binding capacity of the perfusion media. They also acknowledge with thanks the assistance of Miss Claudia Chalybäus and Miss Mechthild Napp.

\section{References}

1. Gollan, F. \& Clark Jr., L. C. (1966), The Physiologist 9, 191.

2. Linn, B. S., Canada, W. D., Breton, M. \& Gollan, F. (1967), Surg. Forum 18, 278-279.

3. Triner, L., Verosky, M., Habif, D. V. \& Nahas, G. G. (1970), Fed. Proc. 29, 1778-1781.

4. Goodman, M. N., Parrilla, R. \& Toews, C. J. (1973), Amer.
5. Andjus, R. K., Suhara, K. \& Sloviter, H. A. (1967), J. Appl. Physiol. 22, 1033-1039.

6. Sloviter, H. A. \& Kamimoto, T. (1967), Nature 216, 458461.

7. Krone, W., Huttner, W. B., Kampf, S. C., Rittich, B., Seitz, H. J. \& Tarnowski, W. (1974), Biochim. Biophy s. Acta 372 55-71. 
8. Zander, R. (1974), Res. Exp. Med. 164, 97-109.

9. Ullrich, V. \& Diehl, H. (1971), Eur. J. Biochem. 20, 509512.

10. Staudt, H., Lichtenberger, F. \& Ullrich, V. (1974), Eur. J. Biochem. 46, 99-106.

11. Sargent, J. W. \& Seffl, R. J. (1970), Fed. Proc. 29, 16991703.

12. Pluronic Polyols Toxicity and Irritation Data (1971), 3rd Edition, BASF Wyandotte Corporation, Wyandotte, Michigan.

13. Höller, M. \& Breuer, H. (1974), this J. 12, 398-402.
14. Bartels, H., Bücherl, E., Hertz, C. W., Rodewald, G. \& Schwab, M. (1955), Lungenfunktionsprüfungen, Springer, Berlin-Heidelberg-New York.

15. Bradlow, H. L. (1968), Steroids 11, 265-272.

16. Schimassek, H. (1968), in Stoffwechsel der isoliert perfundierten Leber (Staib, W. \& Scholz, R., eds.) p. 1-10, Springer, Berlin-Heidelberg-New York.

17. Whitsett, T. L., Dayton, P. G. \& McNay, J. L. (1971), J. Pharmacol. Exp. Therap. 177, 246-255.

18. Branch, R. A., Shand, D. G., Wilkinson, G. R. \& Nies, A. S. (1973), J. Pharmacol. Exp. Therap. 184, 515-519.

Prof. Dr. H. Brcuer Inst. für Klin. Chemie und Klinische Biochemie D-5300 Bonn-Venusberg 


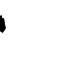

